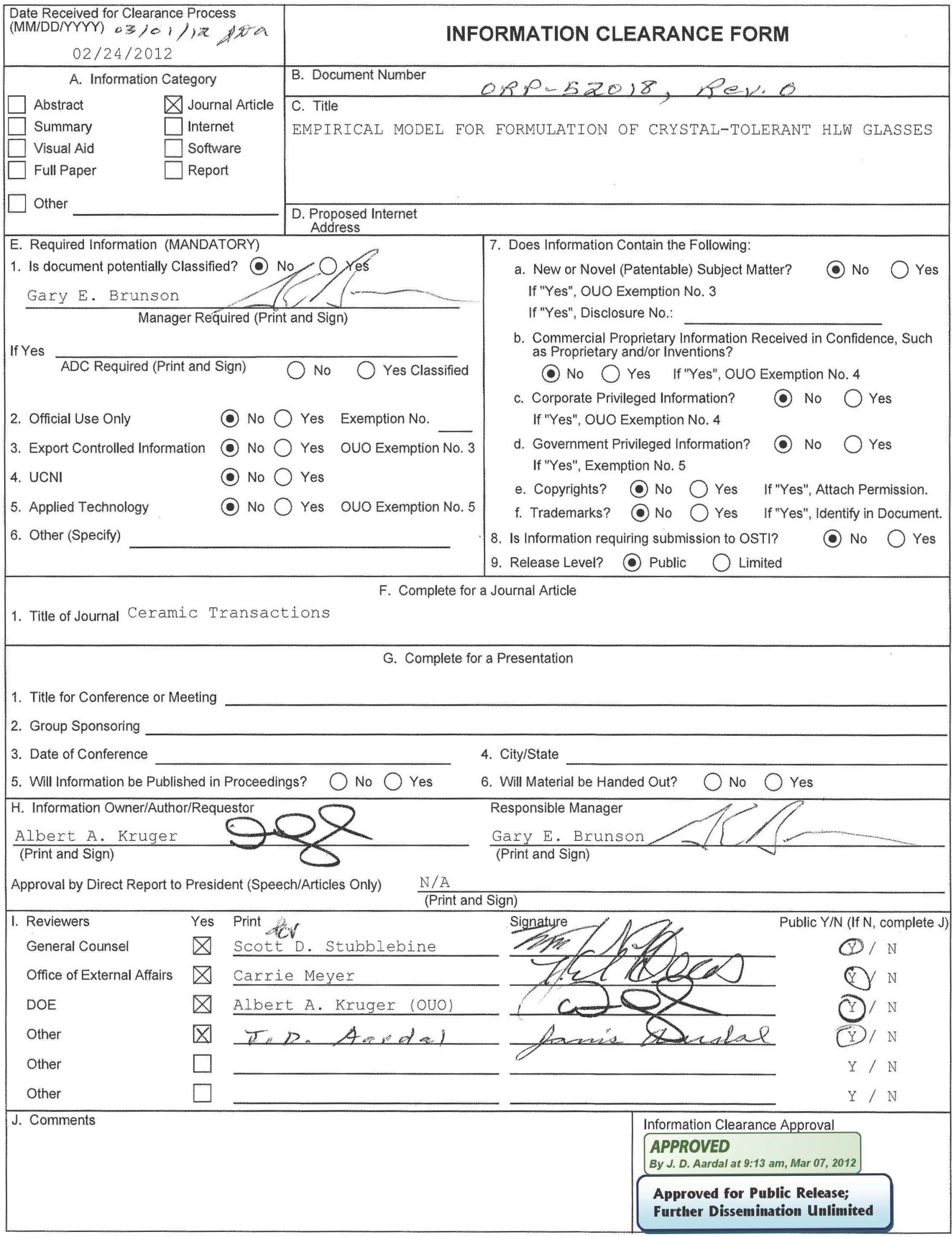


ORP-52018

Revision 0

\section{EMPIRICAL MODEL FOR FORMULATION OF CRYSTAL-TOLERANT HLW GLASSES}

Prepared for the U.S. Department of Energy

Assistant Secretary for Environmental Management

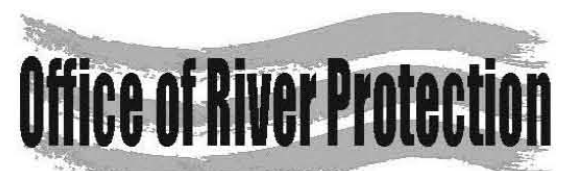

P.O. Box 450

Richland, Washington 99352 
ORP-52018

Revision 0

\section{EMPIRICAL MODEL FOR FORMULATION OF CRYSTAL-TOLERANT HLW GLASSES}

J. Matyas

Pacific Northwest National Laboratory

A. R. Huckleberry

Pacific Northwest National Laboratory

J. D. Vienna

Pacific Northwest National Laboratory
A. A. Kruger

Department of Energy - Office of River Protection

C. A. Rodriguez

Pacific Northwest National Laboratory

Date Published

March 2012

Department of Energy - Office of River Protection

Published in

Ceramic Transactions

Prepared for the U.S. Department of Energy

Assistant Secretary for Environmental Management

P.O. Box 450

Richland, Washington 99352

Copyright License

By acceptance of this article, the publisher and/or recipient acknowledges the U.S. Government's right to retain a non exclusive, royalty-free license in an to any copyright covering this paper.

\section{APPROVED}

By J. D. Aardal at 9:15 am, Mar 07, 2012

Release Approval

Date

Approved for Public Release;

Further Dissemination Unlimited 
ORP-52018

Revision 0

\section{LEGAL DISCLAIMER}

This report was prepared as an account of work sponsored by an agency of the United States Government. Neither the United States Government nor any agency thereof, nor any of their employees, makes any warranty, express or implied, or assumes any legal liability or responsibility for the accuracy, completeness, or any third party's use or the results of such use of any information, apparatus, product, or process disclosed, or represents that its use would not infringe privately owned rights. Reference herin to any specific commercial product, process, or service by trade name, trademark, manufacturer, or otherwise, does not necessarily constitute or imply its endorsement, recommendation, or favoring by the Unites States

Government or any agency thereof or its contractors or subcontractors. The views and opinions of authors expressed herein do not necessarily state or reflect those of the United States Government or any agency thereof.

This report has been reproduced from the best available copy.

Printed in the United States of America 


\title{
EMPIRICAL MODEL FOR FORMULATION OF CRYSTAL-TOLERANT HLW GLASSES
}

\author{
J. Matyáśs ${ }^{1}$, A. Huckleberry ${ }^{1}$, C.A. Rodriguez ${ }^{1}$, J.D. Vienna ${ }^{1}$, A.A. Kruger ${ }^{2}$ \\ 1. Pacific Northwest National Laboratory \\ Richland, WA, USA \\ 2. Office of River Protection \\ Richland, WA, USA
}

ABSTRACT

Historically, high-level waste (HLW) glasses have been formulated with a low liquidus temperature $\left(\mathrm{T}_{\mathrm{L}}\right)$, or temperature at which the equilibrium fraction of spinel crystals in the melt is below 1 vol $\%\left(\mathrm{~T}_{0.01}\right)$, nominally below $1050^{\circ} \mathrm{C}$. These constraints cannot prevent the accumulation of large spinel crystals in considerably cooler regions $\left(\sim 850^{\circ} \mathrm{C}\right)$ of the glass discharge riser during melter idling and significantly limit the waste loading, which is reflected in a high volume of waste glass, and would result in high capital, production, and disposal costs. A developed empirical model predicts crystal accumulation in the riser of the melter as a function of concentration of spinel-forming components in glass, and thereby provides guidance in formulating crystal-tolerant glasses that would allow high waste loadings by keeping the spinel crystals small and therefore suspended in the glass.

\section{INTRODUCTION}

The high-level radioactive waste (HLW) from the Hanford and Savannah River Sites is being vitrified in stable borosilicate glass for long-term storage and disposal. This process is time consuming and expensive because it is highly dependent on loading of HLW in glass and on the rate of HLW glass production. The current HLW melters are projected to operate in an inefficient manner as they are subjected to artificial constraints that limit waste loading to far below its intrinsic level. ${ }^{1}$ These constraints, such as liquidus temperature $\left(T_{L}\right)$ of glass or the temperature at which the equilibrium fraction of spinel crystals in the melt is below $1 \mathrm{vol} \%$ $\left(\mathrm{T}_{0.01}\right)$, nominally below $1050^{\circ} \mathrm{C}$, were imposed to prevent clogging of the melter with spinel crystals that can accumulate at the bottom and in the glass discharge riser based upon operational experience with static melters (i.e., non-bubbled). ${ }^{2}$

To protect the melter from detrimental accumulation of spinel crystals, attention has been focused on studying the settling of spinel crystals in molten glasses ${ }^{3-6}$ as well as transparent liquids $^{7,8}$. Lamont and $\mathrm{Hrma}^{4}$ observed the parabolic shape of the settling front indicating that the settling crystals generated a convective cell within the melt. Klouzek et al. ${ }^{5}$ determined that the measured settling distances between the glass level and the uppermost crystals in the centerline of the crucible were less than $10 \%$ smaller than the distances calculated with the modified Stoke's law. Matyas et al. ${ }^{3}$ determined the accumulation rate of crystals as a function of spinel forming components and noble metals, and revealed a beneficial effect of suppressing the crystal size and accumulation rate through additions of $\mathrm{Fe}$ and noble metals. Matlack et al. reported that the high-crystal content glasses of up to $4.2 \mathrm{vol} \%$ at $950^{\circ} \mathrm{C}$ have been successfully discharged from the DuraMelter ${ }^{\circledR}$ DM-100 after about 8 days of melter idling at $950^{\circ} \mathrm{C}$. $^{6}$

The goal of this work was to develop an empirical linear model of spinel settling that can predict crystal accumulation in the riser as a function of glass composition and therefore provide the guidance to formulate crystal-tolerant glasses for higher waste loading. By keeping the spinel 
crystals small and therefore limiting spinel deposition in the melter, these glasses will allow high waste loading without decreasing melter lifetime.

\section{EXPERIMENTAL}

Glass Matrix Design and Fabrication

Glass matrix of twelve compositions was developed by changing concentrations of $\mathrm{Cr}_{2} \mathrm{O}_{3}, \mathrm{NiO}, \mathrm{Fe}_{2} \mathrm{O}_{3}, \mathrm{ZnO}, \mathrm{MnO}, \mathrm{Al}_{2} \mathrm{O}_{3}$, and noble metals $\left(\mathrm{Rh}_{2} \mathrm{O}_{3}\right.$ and $\left.\mathrm{RuO}_{2}\right)$ one or two components-at-a-time from the baseline glass composition (BL) while proportionally decreasing the concentration of all other components. The concentration of these components was varied to encompass their variation in Hanford HLW, see Table I. Table II shows the composition of designed glasses, including the baseline glass.

Table I. Concentration Variation of Noble Metals, Cr, Ni, Fe, Zn, Mn, and Al in Hanford HLW in Mass Fraction of Oxides.

\begin{tabular}{|l|c|c|}
\hline Component & Minimum & Maximum \\
\hline $\mathrm{Rh}_{2} \mathrm{O}_{3}$ & $1.1 \mathrm{E}-08$ & 0.0004 \\
\hline $\mathrm{RuO}_{2}$ & $2.8 \mathrm{E}-06$ & 0.0024 \\
\hline $\mathrm{Cr}_{2} \mathrm{O}_{3}$ & 0.0027 & 0.0584 \\
\hline $\mathrm{NiO}$ & 0.0012 & 0.0351 \\
\hline $\mathrm{Fe}_{2} \mathrm{O}_{3}$ & 0.0140 & 0.5244 \\
\hline $\mathrm{ZnO}$ & 0.0005 & 0.0181 \\
\hline $\mathrm{MnO}$ & 0.0018 & 0.0668 \\
\hline $\mathrm{Al}_{2} \mathrm{O}_{3}$ & 0.0704 & 0.7350 \\
\hline
\end{tabular}

Glass batches were prepared from AZ-101 simulant and additives $\left(\mathrm{H}_{3} \mathrm{BO}_{3}, \mathrm{Li}_{2} \mathrm{CO}_{3}\right.$, $\mathrm{Na}_{2} \mathrm{CO}_{3}$, and $\mathrm{SiO}_{2}$ ). Extra $\mathrm{Cr}, \mathrm{Ni}, \mathrm{Fe}, \mathrm{Zn}, \mathrm{Mn}$, and $\mathrm{Al}$ were added as $\mathrm{Cr}_{2} \mathrm{O}_{3}, \mathrm{NiO}, \mathrm{Fe}_{2} \mathrm{O}_{3}, \mathrm{ZnO}$, $\mathrm{MnO}, \mathrm{Al}_{2} \mathrm{O}_{3}$, and $\mathrm{Rh}_{2} \mathrm{O}_{3}$. Ruthenium was added in the form of ruthenium nitrosyl nitrate solution drop by drop to $100 \mathrm{~g}$ of $\mathrm{SiO}_{2}$ that was dispersed on a Petri dish. The $\mathrm{SiO}_{2}$ cake was dried in oven at $105^{\circ} \mathrm{C}$ for 1 hour, quenched, and hand-mixed in the plastic bag with the rest of the glass batch. Then, the glass batch was milled in an agate mill for $5 \mathrm{~min}$ to ensure homogeneity.

Glasses were produced in Pt-10\%Rh crucibles following a two-step melting process: 1 ) melting of homogenized glass batches and 2) melting of produced glasses after quenching and grinding. The melting temperature for Ni1.5/A112 and Fe20/Nil.5 glasses was $1250^{\circ} \mathrm{C}$ and $1300^{\circ} \mathrm{C}$, respectively. The other glasses were melted at $1200^{\circ} \mathrm{C}$. 
Table II. Composition of Designed Glasses in Mass Fraction of Oxides and Halogens.

\begin{tabular}{|c|c|c|c|c|c|c|c|c|c|c|c|c|}
\hline Component & $\mathrm{BL}$ & Cr0.6 & $\mathrm{Cr} 1.2$ & Ni1.07 & Ni1.5 & $\mathrm{Ni1} .5 / \mathrm{nm}^{\mathrm{a}}$ & $\mathrm{Fe} 20$ & $\mathrm{Fe} 20 / \mathrm{Ni1} .5$ & Mn1 & $\mathrm{Mn} 2.5$ & Zno.6 & $\mathrm{Ni1} .5 / \mathrm{All} 2$ \\
\hline $\mathrm{Al}_{2} \mathrm{O}_{3}$ & 0.0821 & 0.0817 & 0.0813 & 0.0817 & 0.0814 & 0.0814 & 0.0768 & 0.0760 & 0.0816 & 0.0803 & 0.0816 & 0.1200 \\
\hline $\mathrm{B}_{2} \mathrm{O}_{3}$ & 0.0799 & 0.0796 & 0.0791 & 0.0796 & 0.0792 & 0.0792 & 0.0748 & 0.0739 & 0.0794 & 0.0782 & 0.0794 & 0.0758 \\
\hline $\mathrm{BaO}$ & 0.0009 & 0.0009 & 0.0009 & 0.0009 & 0.0009 & 0.0009 & 0.0008 & 0.0008 & 0.0009 & 0.0009 & 0.0009 & 0.0009 \\
\hline $\mathrm{CaO}$ & 0.0057 & 0.0057 & 0.0056 & 0.0057 & 0.0057 & 0.0056 & 0.0053 & 0.0053 & 0.0057 & 0.0056 & 0.0057 & 0.0054 \\
\hline $\mathrm{CdO}$ & 0.0065 & 0.0065 & 0.0064 & 0.0065 & 0.0064 & 0.0064 & 0.0061 & 0.0060 & 0.0065 & 0.0064 & 0.0065 & 0.0062 \\
\hline $\mathrm{Cr}_{2} \mathrm{O}_{3}$ & 0.0017 & 0.0060 & 0.0120 & 0.0017 & 0.0017 & 0.0017 & 0.0016 & 0.0016 & 0.0017 & 0.0017 & 0.0017 & 0.0016 \\
\hline $\mathrm{F}$ & 0.0001 & 0.0001 & 0.0001 & 0.0001 & 0.0001 & 0.0001 & 0.0001 & 0.0001 & 0.0001 & 0.0001 & 0.0001 & 0.0001 \\
\hline $\mathrm{Fe}_{2} \mathrm{O}_{3}$ & 0.1451 & 0.1445 & 0.1436 & 0.1445 & 0.1438 & 0.1438 & 0.2000 & 0.2000 & 0.1442 & 0.1420 & 0.1443 & 0.1377 \\
\hline $\mathrm{K}_{2} \mathrm{O}$ & 0.0034 & 0.0034 & 0.0034 & 0.0034 & 0.0034 & 0.0034 & 0.0032 & 0.0031 & 0.0034 & 0.0033 & 0.0034 & 0.0032 \\
\hline $\mathrm{Li}_{2} \mathrm{O}$ & 0.0199 & 0.0198 & 0.0197 & 0.0198 & 0.0197 & 0.0197 & 0.0186 & 0.0184 & 0.0198 & 0.0195 & 0.0198 & 0.0189 \\
\hline $\mathrm{MgO}$ & 0.0013 & 0.0013 & 0.0013 & 0.0013 & 0.0013 & 0.0013 & 0.0012 & 0.0012 & 0.0013 & 0.0013 & 0.0013 & 0.0012 \\
\hline $\mathrm{MnO}$ & 0.0035 & 0.0035 & 0.0035 & 0.0035 & 0.0035 & 0.0035 & 0.0033 & 0.0032 & 0.0100 & 0.0250 & 0.0035 & 0.0033 \\
\hline $\mathrm{Na}_{2} \mathrm{O}$ & 0.1866 & 0.1858 & 0.1847 & 0.1858 & 0.1850 & 0.1849 & 0.1746 & 0.1726 & 0.1854 & 0.1826 & 0.1855 & 0.1771 \\
\hline $\mathrm{NiO}$ & 0.0064 & 0.0064 & 0.0063 & 0.0107 & 0.0150 & 0.0150 & 0.0060 & 0.0150 & .0064 & 0.0063 & 0.0064 & 0.0150 \\
\hline $\mathrm{P}_{2} \mathrm{O}_{5}$ & 0.0032 & 0.0032 & 0.0032 & 0.0032 & 0.0032 & 0.0032 & 0.0030 & 0.0030 & 0.0032 & 0.0031 & 0.0032 & 0.0030 \\
\hline $\mathrm{SiO}_{2}$ & 0.4031 & 0.4014 & 0.3989 & 0.4014 & 0.3996 & 0.3995 & 0.3772 & 0.3729 & 0.4005 & 0.3944 & 0.4008 & 0.3825 \\
\hline $\mathrm{SO}_{3}$ & 0.0008 & 0.0008 & 0.0008 & 0.0008 & 0.0008 & 0.0008 & 0.0007 & 0.0007 & 0.0008 & 0.0008 & 0.0008 & 0.0008 \\
\hline $\mathrm{TiO}_{2}$ & 0.0003 & 0.0003 & 0.0003 & 0.0003 & 0.0003 & 0.0003 & 0.0003 & 0,0003 & 0.0003 & 0.0003 & 0.0003 & 0.0003 \\
\hline $\mathrm{ZnO}$ & 0.0002 & 0.0002 & 0.0002 & 0.0002 & 0.0002 & 0.0002 & 0.0002 & 0.0002 & 0.0002 & 0.0002 & 0.0060 & 0.0002 \\
\hline $\mathrm{ZrO}_{2}$ & 0.0416 & 0.0414 & 0.0412 & 0.0414 & 0.0412 & 0.0412 & 0.0389 & 0.0385 & 0.0413 & 0.0407 & 0.0414 & 0.0395 \\
\hline $\mathrm{Cl}$ & 0.0002 & 0.0002 & 0.0002 & 0.0002 & 0.0002 & 0.0002 & 0.0002 & 0.0002 & 0.0002 & 0.0002 & 0.0002 & .0002 \\
\hline $\mathrm{Ce}_{2} \mathrm{O}_{3}$ & 0.0020 & 0.0020 & 0.0020 & 0.0020 & 0.0020 & 0.0020 & 0.0019 & 0.0019 & 0.0020 & 0.0020 & 0.0020 & 0.0019 \\
\hline $\mathrm{CoO}$ & 0.0001 & 0.0001 & 0.0001 & 0.0001 & 0.0001 & 0.0001 & 0.0001 & 0.0001 & 0.0001 & 0.0001 & 0.0001 & 0.0001 \\
\hline $\mathrm{CuO}$ & 0.0004 & 0.0004 & 0.0004 & 0.0004 & 0.0004 & 0.0004 & 0.0004 & 0.0004 & 0.0004 & 0.0004 & 0.0004 & 0.0004 \\
\hline $\mathrm{La}_{2} \mathrm{O}_{3}$ & 0.0022 & 0.0022 & 0.0022 & 0.0022 & 0.0022 & 0.0022 & 0.0021 & 0.0020 & 0.0022 & 0.0022 & 0.0022 & 0.0021 \\
\hline $\mathrm{Nd}_{2} \mathrm{O}_{3}$ & 0.0018 & 0.0018 & 0,0018 & 0.0018 & 0.0018 & 0.0018 & 0.0017 & 0.0017 & 0.0018 & 0.0018 & 0.0018 & 0.0017 \\
\hline $\mathrm{SnO}_{2}$ & 0.0010 & 0.0010 & 0.0010 & 0.0010 & 0.0010 & 0.0010 & 0.0009 & 0.0009 & 0.0010 & 0.0010 & 0.0010 & 0.0009 \\
\hline Total & 1.0000 & 1.0000 & 1.0000 & 1.0000 & 1.0000 & 0.9997 & 1.0000 & 1.0000 & 1.0000 & 1.0000 & 1.0000 & 1.0000 \\
\hline
\end{tabular}

${ }^{a}$ Added $0.0003 \mathrm{Rh}_{2} \mathrm{O}_{3}$ and $2.9 \mathrm{E}-5 \mathrm{RuO}_{2}$

\section{Settling experiments}

The double crucible test was used to study the accumulation of spinel crystals. ${ }^{3,8}$ The alumina crucible was nested in the big silica crucible, hold in place with the core-drilled silica crucible, and covered with molten glass to eliminate the Marangoni convection in the meniscus and bubble generation at the bottom of silica crucibles. First, glass powders were melted in Pt$10 \% \mathrm{Rh}$ crucible at $1200^{\circ} \mathrm{C}$ for $1 \mathrm{~h}$ to dissolve spinel crystals that might formed during the quenching of the glass. Then, the crucible was removed from the melting furnace and molten glass was poured into three double crucibles that were rested inside the furnace at $850^{\circ} \mathrm{C}$, mimicking the temperature in the glass discharge riser. The crucibles were removed at various times and cross-sectioned. The rectangular pieces $3 \mathrm{~cm}$ wide and $5 \mathrm{~cm}$ long were cut out from the bottom of the crucibles, thin-sectioned, and analyzed with scanning electron microscopy- 
electron dispersive spectroscopy (SEM-EDS) and Clemex image analysis to determine the thickness of the spinel sludge layer.

\section{Empirical Model of Spinel Crystal Settling}

Three stages were identified during the settling experiments in the double crucibles: 1 ) latency period with no settling, 2) settling period with constant settling rate of spinel, and 3) end of settling period with a low and gradually decreasing settling rate of spinel due to a smaller and smaller number of settling crystals. Only the sludge layer thickness data for glasses that were collected during the constant settling rate period were used to build an experimental model predicting crystal accumulation in the glass discharge riser as a function of seven major components $\left(\mathrm{Al}_{2} \mathrm{O}_{3}, \mathrm{Cr}_{2} \mathrm{O}_{3}, \mathrm{Fe}_{2} \mathrm{O}_{3}, \mathrm{ZnO}, \mathrm{MnO}, \mathrm{NiO}\right.$, and Others $)$. The constant settling rate allowed us to use a general linear model in the form:

$$
h=\sum_{i=1}^{7} h_{i} x_{i}+t \sum_{i=1}^{7} s_{i} x_{i}
$$

where $h_{i}$ is a compositional dependent intercept coefficient $(\mu \mathrm{m}), x_{i}$ is the $i$-th component mass fraction, $t$ is the settling time $(\mathrm{h})$, and $s_{i}$ is a compositional dependent velocity coefficient $(\mu \mathrm{m} / \mathrm{h})$.

\section{RESULTS AND DISCUSSION}

Table III shows the calculated coefficients $h_{i}$ and $s_{i}, \mathrm{R}^{2}$ (expresses the fraction of the variability accounted for by the model), and $R_{a d j}^{2}$ (adjust $\mathrm{R}^{2}$ for the number of parameters used in fitting the model). Negative coefficients $s_{i}$ for $\mathrm{Al}_{2} \mathrm{O}_{3}$ and $\mathrm{Fe}_{2} \mathrm{O}_{3}$ suggest that these components decrease the settling rate of crystals. In contrast, additions of $\mathrm{MnO}, \mathrm{ZnO}, \mathrm{Cr}_{2} \mathrm{O}_{3}$, and $\mathrm{NiO}$ to the baseline glass increase the settling rate. Nickel oxide stands out as the most troublesome component with a more than six times faster settling rate than, e.g., Cr-rich glass. The detrimental effect of this component on the settling rate can be significantly suppressed by introducing the noble metals or $\mathrm{Fe}_{2} \mathrm{O}_{3}$ to the glass. The negative coefficients $h_{i}$ for $\mathrm{MnO}, \mathrm{ZnO}$, $\mathrm{Cr}_{2} \mathrm{O}_{3}$, and $\mathrm{NiO}$ only indicate, but do not predict, the length of the latency period. This period is dependent on the initial growth rate of crystals to the size at which crystals start to settle.

Table III. Component Coefficients Calculated with PNNL Model

\begin{tabular}{|l|c|c|}
\hline Components & $h_{i}(\mu \mathrm{m})$ & $s_{i}(\mu \mathrm{m} / \mathrm{h})$ \\
\hline $\mathrm{Al}_{2} \mathrm{O}_{3}$ & 8816.97 & -350.41 \\
\hline $\mathrm{Fe}_{2} \mathrm{O}_{3}$ & 4304.182 & -49.9117 \\
\hline $\mathrm{MnO}$ & -7498.52 & 259.3812 \\
\hline $\mathrm{ZnO}$ & -12257.6 & 313.0436 \\
\hline $\mathrm{Cr}_{2} \mathrm{O}_{3}$ & -40257.3 & 443.5807 \\
\hline $\mathrm{NiO}$ & -197477 & 2672.734 \\
\hline Others & -366.91 & 27.00287 \\
\hline $\mathrm{R}^{2}$ & \multicolumn{2}{|c|}{0.985} \\
\hline $\mathrm{R}^{2}$ adj & \multicolumn{2}{|c|}{0.975} \\
\hline
\end{tabular}


Figure 1 shows the predictive versus measured thicknesses of a spinel sludge layer for tested glasses. The linear empirical model with coefficients $h_{i}$ and $s_{i}$ expressed as a linear function of mass fractions of seven major components fits the 35 data points reasonably well, $\mathrm{R}^{2}=0.985$, and can become an efficient tool to formulate the crystal-tolerant glasses that would ultimately allow a substantial increase in the waste loading.

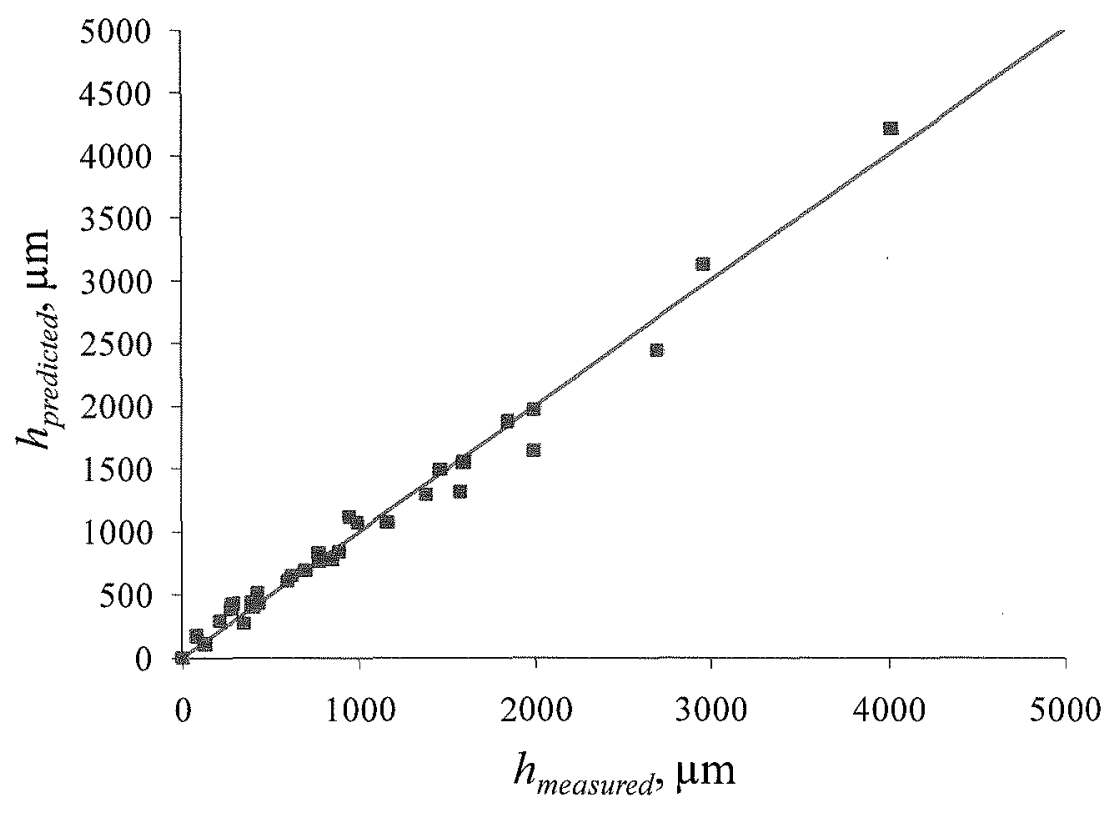

Figure 1. Predicted vs. Measured Spinel Layer Thickness.

\section{CONCLUSION}

The developed 7-component model can predict very well the crystal accumulation in the riser as a function of glass composition and therefore allows higher waste loadings, and at the same time protects the HLW glass melter from detrimental accumulation of spinel in the glass discharge riser during melter idling. In the future work, we plan to expand the compositional region covered by our model, and thereby improve its predictive performance. We will also elucidate the accumulation rate of spinel crystals at temperatures above $850^{\circ} \mathrm{C}$ because the temperature in the glass discharge riser varies and can exceed $950^{\circ} \mathrm{C}$ during melter idling. Additionally, we will investigate the impact of different components on agglomeration of particles and on the shape, size, and concentration of crystals.

\section{ACKNOWLEDGEMENT}

This work was funded by the U.S. Department of Energy's Environmental Management Program EM20. Pacific Northwest National Laboratory is operated by Battelle for the U.S. Department of Energy under Contract DE-AC05-76RL01830.

\section{REFERENCES}

${ }^{1}$ D.S. Kim and J.D. Vienna, Influence of Glass Property Restrictions on Hanford Glass Volume, Ceramic Transactions 132, 105-115 (2002). 
${ }^{2}$ P. Hrma, J. Matyáš, and D.S. Kim, Evaluation of Crystallinity Constraint for HLW Glass Processing, Ceramic Transactions 143, 133-140 (2003).

${ }^{3}$ J. Matyáš, J.D. Vienna, A. Kimura, M. Schaible, and R.M.Tate, Development of CrystalTolerant Waste Glasses, Ceramic Transactions 222, $41-51$ (2010).

${ }^{4} \mathrm{~J}$. LaMont and P. Hrma, A Crucible Study of Spinel Settling in a High-Level Waste Glass, Ceramic Transactions 87, 343-348 (1998).

${ }^{5}$ J. Kloužek, J. Alton, T.J. Plaisted, and P. Hrma, Crucible Study of Spinel Settling in High-Level Waste Glass, Ceramic Transactions 119, 301-308 (2001).

${ }^{6}$ K.S. Matlack, W.K. Kot, W. Gong, W. Lutze, I.L. Pegg, and I. Joseph, Effects of High Spinel and Chromium Oxide Crystal Contents on Simulated HLW Vitrification in DM100 Melter Tests, Department of Energy Office of River Protection, VSL-09R1520-1 (2009).

${ }^{7}$ J. Matyáš, J.D. Vienna, and M.J. Schaible, Determination of Stokes Shape Factor for Single Particles and Agglomerates, Ceramic Transactions 227, 195-203 (2011).

${ }^{8}$ J. Matyáš, J.D. Vienna, M.J. Schaible, C.P. Rodriquez, J.V. Crum, Development of CrystalTolerant High-Level Waste Glasses, Pacific Northwest National Laboratory, Richland, Washington, PNNL-20072 (2010). 